\title{
ANALYSIS OF DISTRIBUTION PATTERN AND PROPERTIES OF PUBLIC SECURITY CRIMES IN AN URBAN ENVIRONMENT: CASE OF İMITT CITY
}

\author{
Deniz GERÇEK ${ }^{1}$, İsmail Talih GÜVEN²*
}

${ }^{1}$ Kocaeli University, Faculty of Architecture and Design, Department of Urban Planning, Kocaeli, Türkiye ${ }^{2}$ Kocaeli University, Faculty of Architecture and Design, Department of Architecture, Kocaeli, Türkiye

Keywords
Crime,
Crime maps,
Geographical Information
System (GIS),
Urban Quality of Life,

\begin{abstract}
Conventional demonstrations for crime mapping with pin maps evolved into computer-based representations with the advent of Geographic Information Systems (GIS). GIS permits information layering to produce detailed descriptions of conditions and analyses relationships among variables. GIS and crime mapping can be utilized as devices to represent conditions of the space, model the distribution of crime across the space and relate these two to discover reasons contributing to crime. Crime as a measure of security in urban space is closely related with Urban Quality of Life.
\end{abstract}

In this study, security crime rates at district basis is explored in İzmit city which has been subject to excess urbanization and industrialization during the past decades. Locations where crimes took place and the related attributes were stored in a database within a GIS. Crime data obtained at administrative district level for the city center and surrounding dense urban areas were analysed. Number of crime and type of crime were then evaluated for their relation with districts characteristics and basic offender characteristics to understand pattern of crime in the city and major properties of criminals such as age, education level and gender. Outcomes are plotted as graphics and mapped to convey the patterns and properties associated with public security crimes. Outcomes that portray spatial pattern of crime vs socioeconomic status and specific profiles of the offenders at district basis may help law enforcement agencies and local administratives to ease local weaknesses specific to districts and take measures to reduce rate of crime.

\section{ASAYIŞ SUÇLARININ KENTSEL ALANDA DAĞILIMI VE ÖZELLÍKLERİNIN ANALİZİ: İZMİT KENTI ÖRNEĞİ}

\begin{tabular}{ll}
\hline Anahtar Kelimeler & Öz \\
\hline Suç, & Suç noktalarının basılı haritalar üzerine işaretlenerek gösterildiği eski yöntemler, \\
Suç haritaları, & Coğrafi Bilgi Sistemlerinin (CBS) ortaya çıkışıla birlikte bilgisayar destekli grafik \\
Kentsel Yaşam Kalitesi & temsil yöntemlerine dönüşmüştür. Ayrıca, CBS durum ve olguların katman yapısılala \\
& detaylı olarak temsil edilmesini ve bu olgu ve durumların birbiri ile ilişkisini analiz \\
& etmeyi sağlar. CBS ve suç haritaları mekanla ilgili durumları temsil etmeye, suçun \\
& mekandaki dağllımını modellemeye ve bu ikisinin birbiri ile ilişkisini analiz ederek \\
& suça neden olan mekânsal bağlamı anlamaya yardımcı olur. Suç olgusu, kentsel \\
& alanda güvenliğin bir ölçütü olarak Kentsel Yaşam Kalitesiyle de yakından ilgilidir. \\
& Bu çalışmada, yoğun sanayileşme ve kentleşmenin yaşandığı İzmit kentinde asayiş \\
& suçları oranları alansal bazda incelenmektedir. Suçun meydana geldiği yer ve ilgili \\
& bilgiler bir CBS veri tabanına geçirilmiştir. Mahalle düzeyinde elde edilen bu suç \\
& verileri kent merkezi ve kent merkezi çevresini kapsamaktadır. Suç sayısı ve suç \\
& türü suçun dağllımı ve örüntüsünü anlamak üzere, mahallelerin karakteristik \\
& özellikleri ve suçluların yaş, eğitim ve cinsiyet gibi temel özellikleri ile \\
\hline
\end{tabular}

\footnotetext{
* Ilgili yazar / Corresponding author: talihguven@yahoo.com
} 
karşılaştırılmıştır. Asayiş suçları ile ilgili elde edilen bu sonuçlar grafik ve harita biçiminde gösterilmiştir. Mahallelerin sosyo-ekonomik vb. karakteristik özelikleri ile ve suçluların temel özellikleri ile suç arasında tespit edilen ilişkiler, suçla mücadele eden kurumların ve yerel yönetimlerin bölgelere özgü zayıflıkların giderilmesinde özel önlemler almasına yardımcı olur.

\section{Alıntı / Cite}

Gerçek D., Guven İ. T.,(2018). Analysis of Distribution Pattern and Properties of Public Security Crimes in an Urban Environment: Case of İzmit City, Journal of Engineering Sciences and Design, 6(2), 265-272.

\section{Yazar Kimliği / Author ID (ORCID Number)}

D. Gerçek, 0000-0003-4818-9802

İ. T. Güven, 0000-0002-1048-3494

\begin{tabular}{l|l}
\hline Başvuru Tarihi /Submission Date & 05.12 .2017 \\
Revizyon Tarihi / Revision Date & 26.03 .2018 \\
Kabul Tarihi / Accepted Date & 09.05 .2018 \\
Yayım Tarihi / Published Date & 23.06 .2018 \\
\hline
\end{tabular}

\section{Introduction}

For crime to occur, there are three elements that should be existing namely; motivated offender, vulnerable target, and insufficient guardianship. Role of place in crime however is very obvious, that is crime is not randomly distributed and it has an inherent geographical quality. To represent locations of crime occurrences, pin maps have been used in the police offices for decades. These conventional demonstrations for crime mapping combined with pattern observations were utilized to better understand crime. Today, crime mapping and spatial analysis carried through Geographic Information Systems (GIS) are far useful to understand where crime is likely to occur and the motives behind it (Liu and Eck, 2008). Besides its benefits, assessments conducted on crime mapping through GIS are limited. A primary reason relates to the multiplicity of functions of a GIS (Zhang et al, 2016; Garson and Vann, 2001). At the same time, the diversity of the applications of a GIS also inflates expected outcomes. Multiplicity of functions, variations of adaptation, and diversity of outputs in different law enforcement agencies make the specification and measurement of benefits of GIS very difficult (Zhang et al, 2016).

Place where crime occurs and other geographic features associated with a criminal incident provide a lot of information about crime and possible criminals. This information assist in the design of prevention, assessment of programs, and help get a better perspective of environmental reasons that may be related to criminal incidents. Hot points of incidents and regions with high criminal rates are therefore necessary to analysts. Computerization of police records has brought in the realization that this material can be used for inferring statistical and spatial information automatically (Ratcliffe, 2004). A Geographic Information System (GIS) that is capable of storing real world data as layers of information, display, manipulate analyze and interpret spatial data is utilized in vast amount of applications including criminality. GIS utilized in crime analysis permits recognition of patterns sometimes hidden and often not perceived by the police and authorities.

Crime incidences are almost always reported to include the geographic location together with other information associated with the criminal. This information is the basis for conventional pin maps as well as point displays and analyses in GIS. Crime locations represented as points are analyzed to produce crime density maps usually conveyed through Kernel Analysis. Kernel Analysis projects a more realistic map of the crime hotspots through weighing incidents that occur closer (Levine, 2001; Hill and Paynich, 2014). Crime density maps are then analyzed together with other information relevant to urban environments (Ergun and Yirmibeşoğlu, 2007). Given that high levels of crime may occur simply because of the high population in particular places, crime rate as one of the most common measures in crime analysis may employ the residential population as the control (Andresen, 2006).

In this study we utilized the available crime data that is retrieved at local administrative districts /wards (mahalle) level in İzmit city.. Public security crimes are then mapped on district basis to show the spatial distribution of crime occurrences across the city. On the other hand, characteristics about urban environment, such as area of urban green land, area of social facilities like schools, clinics, etc. per person for each district and rent per $\mathrm{m} 2$ of flat as a socioeconomic indicator were evaluated. Moreover, criminals basic properties; namely, age, education level and gender for each district is evaluated and anomalies about these properties were highlighted to point out any possible specific situation.

\section{Study Area}

The study area, İmit is the central subprovince of Kocaeli. With its proximate location to İstanbul, strong 
transportation connections, suitable topography and climate, it has drastically transformed into an industrial region since 1960's. Together with Turkish heavy industrial leap, governmental policies that stressed the need for modernization, industrialization and urbanization lead urban growth in major cities reached excess levels (Payne, 1993). Thus, rapid industrialization and demand of work power severely increased population in İzmit. Immigrants were comprised of people coming from across Turkey, mainly from the rural parts of northern and eastern Turkey that are far less civilized. The conventional and authentic social structure of the city then transformed into a diverse characteristic that accommodate people from many different origins within the country. On the other hand, mass settlement demand that lacks a wellorganized city plan brought about the dense and irregular city form that the city still suffers today. Strong trend of urbanization in Kocaeli province where the rate of increase in population is twice the Turkey's average according to the 2011 census (URL1) suggests that the problems brought out with urbanization are likely to retain.

A research on the livability of Turkish provinces in 2011 (URL-2) evaluates 37 parameters including air pollution, teacher per student, rate of unemployment to name a few. A research based on the results of the study evaluated mentioned parameters with Multi Criteria Decision Making (MCDA) methods. Kocaeli is 11th, 24th, or 21th of provinces in livability in Turkey, according to the MCDA methods; SWA, TOPSIS, and GRI respectively (Karaatlı et al., 2015). However, rate of crime (public security) that is one of the parameters of livability, Kocaeli is in 60th order from least to greatest crime rates. This comparison of high livability vs high crime rates highlights the fact that high crime rates of the province is worth a further exploration.

City of İzmit is divided into 51 local administrative districts or wards called "mahalle". In this study we take 29 of the districts. These 29 district sre the wards that constitute city center and surrounding dense settlement areas. Hence, they are the core part of the city with established urban fabric.Industrial regions and suburbs of the city are excluded.

Table 1: Public security crimes in Kocaeli in 2010 (URL-2).

\begin{tabular}{lccc}
\hline $\begin{array}{l}\text { Number of } \\
\text { public security } \\
\text { crimes }\end{array}$ & $\begin{array}{c}\text { Population } \\
(\mathbf{2 0 1 0 )}\end{array}$ & $\begin{array}{c}\text { Crime } \\
\text { per } \mathbf{1 0 0 0}\end{array}$ & $\begin{array}{c}\text { Order in the list } \\
\text { (from least to } \\
\text { greatest) }\end{array}$ \\
\hline $\mathbf{3 2 . 2 3 3}$ & 1.560 .138 & 20,66 & $60^{\text {th }}$ of 81 \\
\hline
\end{tabular}

\section{Materials and Methods}

In this study we explore public security crimes such as robbery, seizure, intrusion and homicide occurred between 2010-2014 in İzmit. The crime data that is not publicly accessible was acquired from the Police Headquarters of the Kocaeli Province after a series of official correspondence. Police crime reports are being stored in computerized systems for the last decade in Turkey. However, the database structure is not purposely designed for conducting spatial analysis. Besides, crime reports were not prepared to locate crime in locational (geographic point coordinates) basis. Location information is stored as text in the address field that complicate an automated query and geocoding operation. Crime data for the study nevertheless could be only retrieved at district level (mahalle). This implies that districts, especially the large ones are treated by the overall crime incidences regardless of the locations where crime occurs.

Various types of public security crimes can be categorized into three broader groups that generalize the type of crimes according to their object of interest:

- offence to people,

- robbery, and

- violating public order.

We obtained crime data including about 40 subtypes of public security crimes. These subtypes were then categorized into broader three types as mentioned above.

Rate of public security crimes were both evaluated for three broader categories and at total.

In this study we employ GIS to explore rate of crime per administrative district versus some social indicators to understand crime pattern those social indicators are;

(i) rate of green space,

(ii) rate of social facilities, and

(iii) average rents that gathered at district level.

Some basic characteristics of the offenders that was stored in the database of crime records were drawn;

(i) age,

(ii) education level, and

(iii) gender of the offender.

These properties were evaluated on district basis to evaluate if there is an anomaly of these properties, such as high rate of young criminals for any or some of the districts.

Offense to people involve all types of offend to another individual like stroke, interception, rape, mutilation, homicide, etc. Robbery involves robbery from the street, home or commercial elements. Violating public order include all types of disturbances that incommode people in various ways, such as making noise.

Total crime numbers including offence to people, robbery, and violating public order per local district is drawn from the database. As each of the districts have different area and population, rationing the number of 
crime with population of the relevant district is regarded as a reasonable means to quantify rate of crime.

\section{Results}

We have categorized various types of security crimes into three broader groups that generalize the type of security crimes: offence to people, robbery, and violating public order. Accordingly, security crimes in İzmit majorly comprise of offence to people, robbery follows it, and public order violation takes a smaller portion (Figure 1). Each of the three types of public security crimes were evaluated on district basis. However, no significant variations were observed in the patterns of these crime types. Therefore, we have confined the study to overall public security crimes.

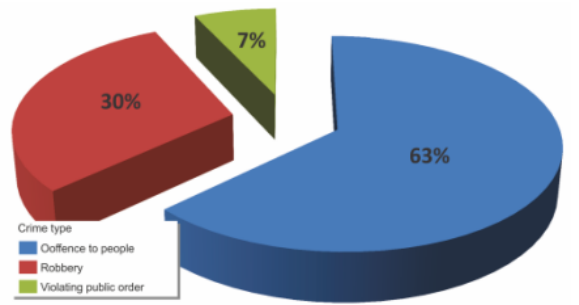

Figure 1: Distribution of types of security crimes across İzmit city for the period 2010-2014

Taking all of the public security crimes into consideration, a descriptive study that portray rate of security crimes for each district was conducted. Data was drawn from the crime records database including all of the public security crimes. These records were ordered for each district. One critical issue is that each district has different extents and different population. In order to affirm a district of high or low criminality, number of crimes for the specific district should be normalized with population of that district. This population information was gathered from the census records. The rate of public security crimes are then given as number of crime per 1000 people at district level (Figure 2). It can be observed at the first glance that districts in the city center and the close vicinity are more prone to criminal activities.

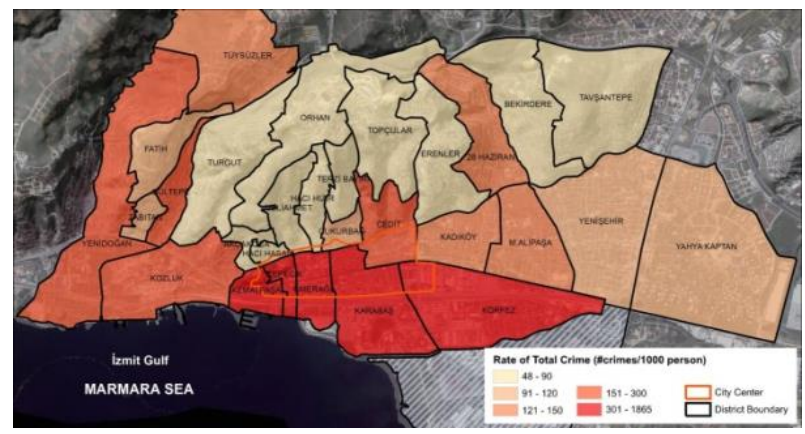

Figure 2. Rate of public security crimes (number of crime per 1000 people) at district level

\subsection{Public Security Crimes and socio-economic Indicators}

Some of the parameters that are assumed to indicate wealth, quality of life and socio-economic status of urban environments such as area of urban green land, area of social facilities like schools, clinics, etc. per person were quantified on district basis across the city. Rate of rents per district is also assumed as a sound indicator- though indirect- of socio-economic status of the districts. Therefore, average amount of rent per $\mathrm{m} 2$ of flat retrieved from online real estate services were used (URL-3). All analysis results including crime rates, social indicators, area and population for each district were gathered in Table 2 .

Table 2. Crime rates, social indicators and demographic data at district level for the study area that is sorted in descending order for crime rates (only first five and last five districts are given)

\begin{tabular}{|c|c|c|c|c|c|c|c|}
\hline District & $\begin{array}{l}\text { Pop. } \\
2015\end{array}$ & $\begin{array}{r}\text { Green } \\
\text { Space } \\
\left(\mathrm{m}^{2 /}\right. \\
\text { Person) }\end{array}$ & $\begin{array}{r}\text { Social } \\
\text { Infrastr. } \\
\left(\mathrm{m}^{2} /\right. \\
\text { Person) }\end{array}$ & $\begin{array}{r}\text { Avg. } \\
\text { Rent } \\
\left(\mathrm{T} / \mathrm{m}^{2}\right)\end{array}$ & $\begin{array}{r}\text { Total } \\
\text { Crime }\end{array}$ & $\begin{array}{r}\text { Crıme Rate } \\
(1000 \\
\text { Person) }\end{array}$ & $\begin{array}{r}\text { Total } \\
\text { Area } \\
\left(\mathrm{m}^{2}\right) \\
\end{array}$ \\
\hline 1 KEMALPAŞA & 691 & 27.1 & 17.14 & 6.5 & 1289 & 1865 & 209792 \\
\hline 2 ÖMERAĞA & 1495 & 2.0 & 4.62 & 8.67 & 2177 & 1456 & 271768 \\
\hline 3 TEPECIK & 1281 & 4.3 & 5.48 & 8.2 & 627 & 489 & 115239 \\
\hline 4 KARABAŞ & 7192 & 8.2 & 8.13 & 8.6 & 2620 & 364 & 791523 \\
\hline \multirow[t]{2}{*}{5 KÖRFEZ } & 5610 & 6.7 & 3.86 & 7.05 & 1932 & 344 & 1121688 \\
\hline & & & & $\cdots$ & $\ldots$ & $\ldots$. & \\
\hline $\begin{array}{l}25 \text { TERZI } \\
\text { BAYIRI }\end{array}$ & 2165 & 0.8 & 0 & 7.05 & 170 & 78 & 223292 \\
\hline 26 BEKIRDERE & 9620 & 7.5 & 52.53 & 5.69 & 699 & 72 & 851615 \\
\hline 27 ORHAN & 3887 & 22.8 & 7.22 & 10.25 & 269 & 69 & 1029544 \\
\hline $28 \mathrm{HAClHIZIR}$ & 4354 & 3.3 & 0 & 7.2 & 275 & 63 & 226910 \\
\hline 29 TOPÇULAR & 7048 & 12.2 & 8.73 & 8.09 & 412 & 58 & 737206 \\
\hline
\end{tabular}

In this study we relate rate of public security crime per district with other social-demographic parameters. Distribution of crime among districts and the different physical and social structures observed in these districts is compared. Number of urban utilities and their sufficiency is regarded as a social indicator in urban environments. A graphic plot demonstrates the urban green spaces and social facilities per capita and average rent for each district ordered for districts from the highest to lowest criminality (Figure 3).

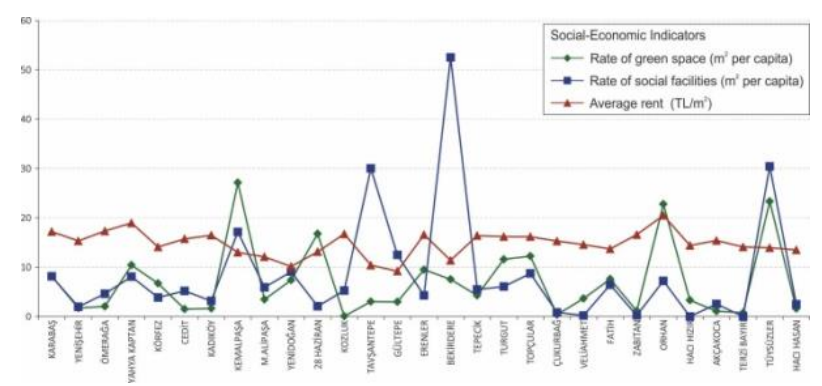

Figure 3. Socio-economic indicators (rate of green spaces, social facilities, and rents) plotted against districts ordered from the highest to lowest criminalities.

Rate of urban green space and rate of social facilities more or less follow a similar pattern, however they portray irregularities seldom peaks and pits. This is mainly because some bigger extent park or a cityscaled health facility may escalate the rates, where in fact the districts may not be well-supplied with these services. However, rent is a more stable measure to 
indicate socio-economic status of the districts through level of preference which intrinsically involve many factors like, quality of housing, proximity to city center and services, environmental quality, etc. Therefore, we took average rent per $\mathrm{m} 2$ as an indicator of socioeconomic status of the districts (Figure 4).

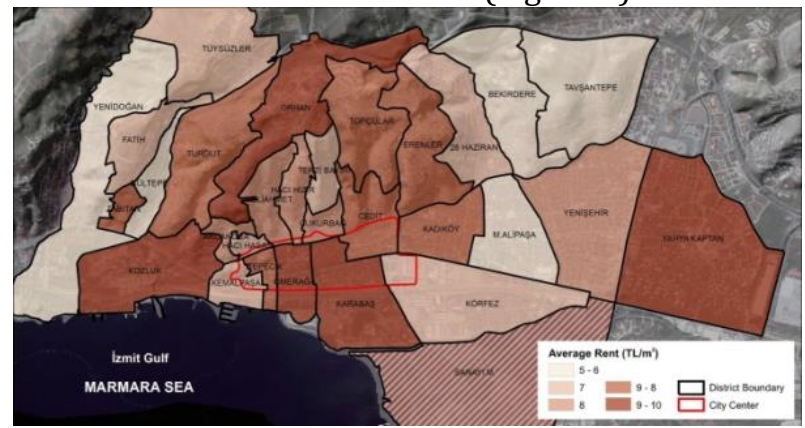

Figure 4. Average rent per $\mathrm{m}^{2}$ flat at district level

Resulting maps and statistical information reveal that there exist some sort of relationship between social status indicators (urban facilities and avg. rent) and crime rates. However this relationship is not regular and directly proportional. Some districts having high social status indicators had very low crime rates while some other had very high, and some districts may have low crime rates even they do have low social indicators. This situation is attributed to intrinsic properties of districts and some patterns of crime across space. In order to evaluate this, a graph representation is given (Figure 5). In the figure, rate of crime is plotted against average rents for the districts. Inliers represent the mediocre crime rates and rents where divergent points represent crime patterns. Accordingly, four patterns were represented;

(i) High criminality - Low social status

(ii) High criminality - High social status

(iii) Low criminality - High social status

(iv) Low criminality - Low social status

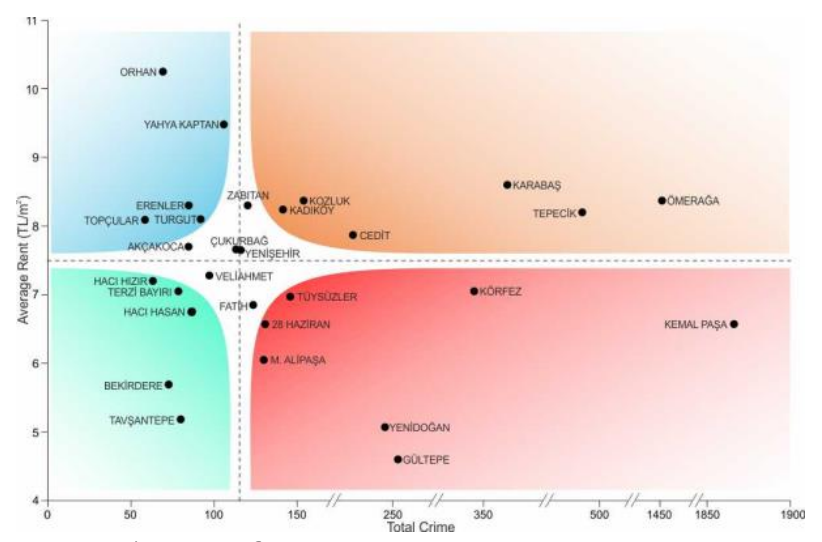

Figure 5. Rate of crime against average rent

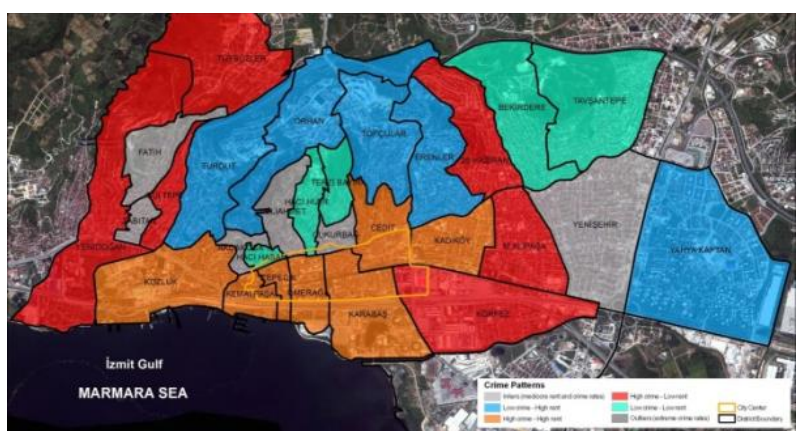

Figure 6 depicts the four divisions with associated colors.

According to the results shown in Figure 5 and 6; High criminality - Low social status (red) districts, 28 Haziran, M.Alipaşa are districts of older city center, when central activities moved to another part of the city (Shown as orange frame in Figure 6), these places were decentralized and experienced a collapse. Tüysüzler, Yenidoğan and Gültepe are cosmopolite regions of low income and extremely vulnerable to criminality.

High criminality - High social status- (orange) districts, Kadıköy, Kozluk, Cedit, Karabaş and Tepecik have similar social properties as other low rent district. However, rents are relatively higher due to vicinity to the city center. These districts are also known for their cosmopolite social structure.

High social status-low criminality (blue) districts, Turgut, Topçular, Erenler, Yahya Kaptan, Orhan are the newer development areas of İzmit that evolved with a proper planning. These districts are mainly comprised of residences with securities and other guards. Therefore it is not surprising that these districts encounter low crime rates.

Low criminality - Low social status (green) districts, Hacıhızır, Terzibayırı, Hacıhasan which are in the same region, that is northern part of the city with sloping terrain are the oldest settlements of the city that lack an adequate plan in the development phase. These districts although having low social indicators have residents of homogeneous culture and background and dominated by close neighborhood relationships which reveal low crime rates.

Districts that are at the right end of the graphic (Karabaş, Tepecik, and, Körfez) have very high in crime rates. These districts comprising the city center are very active in crime as they are the spaces of condensed commercial activities. Rate of crime is derived by dividing the number of crime to population of the district. These regions are also characterized by high day population but night population which is the real number of residents is low that ends up with increased crime rates.

\subsection{Public Security Crimes and Offender Profiles}


Criminal offenders' basic properties; namely, age, education level and gender for each district are evaluated and anomalies about these properties were highlighted to point out any specific situation. Among 29 districts, districts with low number of crime were eliminated because they were assumed to produce insignificant statistics (Çukurbağ, Veliahmet, Fatih, Zabıtan, Orhan, Hacıhızır, Akçakoca, Terzibayırı, Tüysüzler, Hacıhasan).

Rate of young criminals is of critical importance in crime. We have explored there age groups: $>25,25-44$, and $>45$ in district basis. The results convey that young criminals are condensed in central districts and in a group of squatter districts in the northeast part of the city. In the newer settlement areas young criminal rate is fairly low (Figure7, 8).

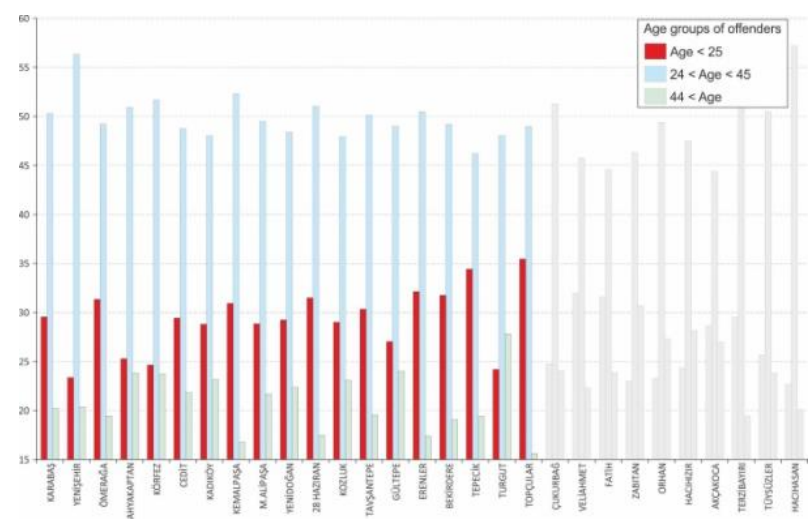

Figure 7. Rate of crimes of different age groups of offenders ordered in highest to lowest total criminality

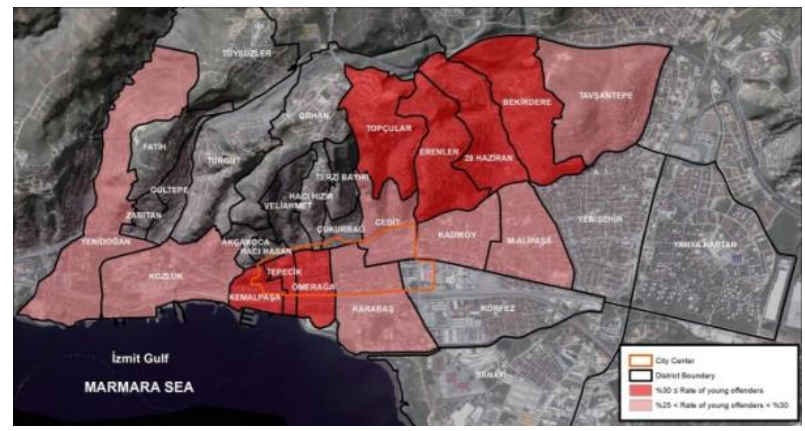

Figure 8. Rate of crimes of young criminals for each district

High criminality is often associated with low education. We explored the education level of criminals per district and tried to figure out if there is and high rate of criminals with low education in district basis. Accordingly, low educated criminals are condensed in some of the central districts, old central district and some of the squatter districts and new districts (Figure 9, 10). As we do not have a demographic data that show rate of all populations' education level at district level, it is not practically proper to assume low educated people are more prone to commit crime given that education level in the district is low already.

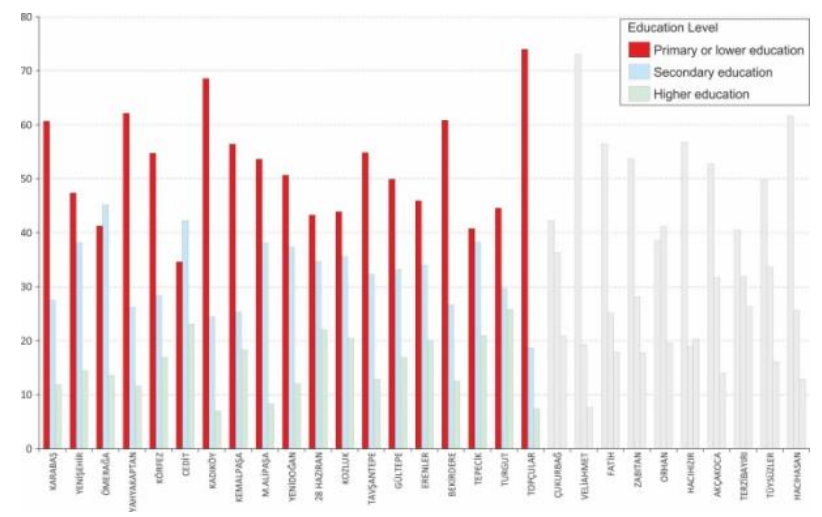

Figure 9. Rate of crimes of different education levels of offenders ordered in highest to lowest total criminality

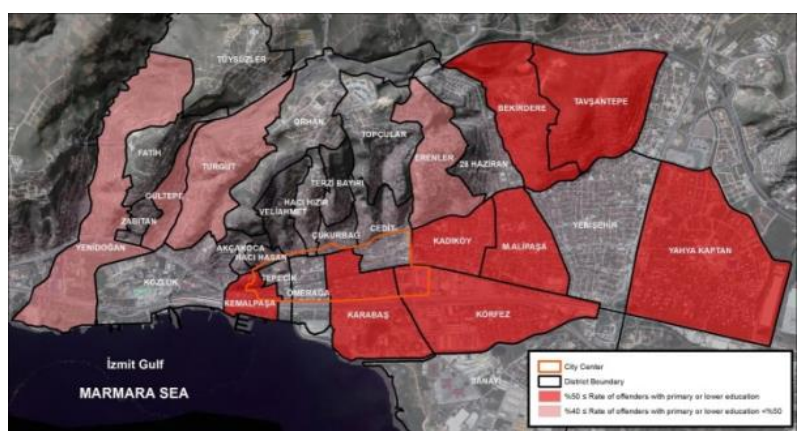

Figure 10. Rate of crimes of low-educated criminals for each district

Finally gender information was evaluated to understand whether there is an anomaly in the rate of genders of offenders. Accordingly, male criminals are twice the females and more for most of the districts. However this is not quite the same for few of the districts in the city center (Figure 11, 12). This is mainly attributed to commercial and business activities and different functions that create diverse occasions for crime that may cause more interest for female.

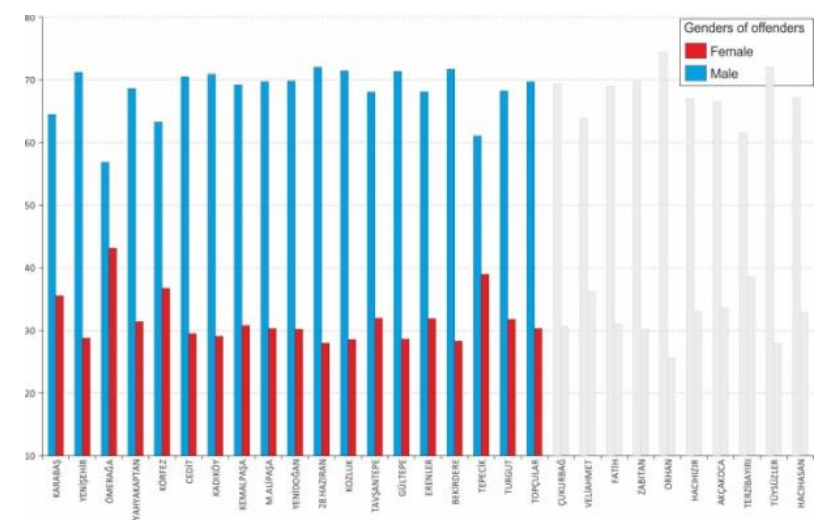

Figure 11. Rate of genders of offenders ordered in highest to lowest total criminality 


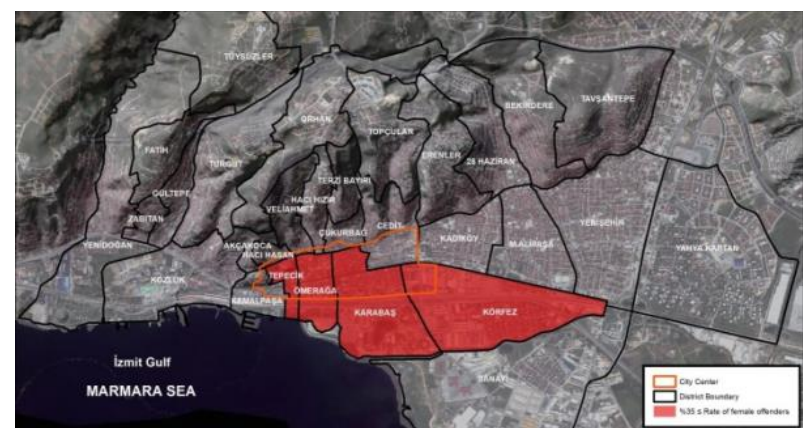

Figure 12. Rate of female criminals for each district

\section{Conclusions}

İzmit has a divisional structure both in physical and socioeconomic levels in residential areas. City has natural and manmade limits such as topography and a national level transportation corridor that shapes the urban growth. Crime rates are highest in the districts of the city center (Kemalpaşa, Tepecik, Ömerağa, Karabaş, Körfez, Cedit). In these districts, majority of land use is allocated to commercial facilities and business, residential population is low but daily population is very high and there is different user quality, quantity, and diversity which are also a challenge for control mechanisms.

Older districts in the close vicinity to city center (north: Akçakoca, Hacıhasan, Veliahmet, Hacıhızır, Terzibayırı) mainly sustain the conventional and authentic social structure of the old city and eventhough not modernized and lack urban facilities they have lowest crime rates due to neighborhood culture and acquaintance.

Districts that are in the west and the east peripheries of the city extents at 1960's are majorly occupied by the immigrants from the rural parts of Turkey with the industrial leap condensed in İzmit and surroundings. Squatter type of settlements of the period still retains their structure despite of some improvements. In most of these districts (Yenidoğan, Fatih, Gültepe, Zabıtan, Kozluk, and Kadıköy, M.Alipaşa, 28 Haziran) high crime rates in squatter areas with diverse sociocultural structure and and a low-educated population coincide with the findings of studies carried out in other countries. However, in other districts of squatters (Bekirdere, Tavşantepe, Erenler) immigrants are majorly from same regions of Turkey. Family ties and $t$ sustained rural life function as a kind of informal control on criminal.

The newest settlement areas in the northern part (Turgut, Orhan, Topçular) was established in the last decades. These settlements are usually sites with private security and isolated from the surrounding. Therefore there is little chance of criminal occasions. Comparisons of crime rates with socio-economic indicators convey that there is not a directly proportional relationship. Low socio-economic status is not directly related with high criminality, as it was practically observed that low socio-economic status and low crime rates is the case for a group of districts and vice versa. Therefore, we utilized this finding to describe districts according to their specific patterns:

(i) High criminality - Low social status

(ii) High criminality - High social status

(iii) Low criminality - High social status

(iv) Low criminality - Low social status

Each type of pattern has its intrinsic properties of crime incidences, therefore measures specific to each of the four types of patterns should be taken.

Analysis on the major properties of criminals were investigated for critical items such as young criminals, low educated criminals and females. Results have shown that there are variations of rates of these critical groups at district level. Some special programs should be formulated in order to reduce criminals of these specific groups in certain districts.

\section{Acknowledgements}

We thank Police Headquarter of the Kocaeli Province for providing the crime data for İzmit districts.

\section{Conflict of Interest}

No conflict of interest was declared by the authors.

\section{References}

Andresen, M. A., 2006. Crime measures and the spatial analysis of criminal activity. Brit. J. Criminology, 46, pp. 258-285.

Ergun, N., Yirmibeșoğlu F., 2007. Distribution of Crime Rates in Different Districts in Istanbul. Turkish Studies, 8(3), pp. 435-455.

Garson, I. B., Vann, G. D., 2001. Crime Mapping and Its Extension to Social Science Analysis. Social Science Computer Review Winter, 19(4), pp. 471-479.

Hill, B., Paynich, R., 2014. Hotspot Analysis in Fundementals of Crime Mapping. Jones and Bartlett Learning, Burlington, MA, pp.219-235.

Karaatlı, M., Ömürbek, N., Budak, İ., Dağ, O., 2015. Çok Kriterli Karar Verme Yöntemleri ile Yaşanabilir Illerin Sıralanması, Selçuk Üniversitesi Sosyal Bilimler Enstitüsü Dergisi, 33, pp. 215-228.

Levine, N., 2001. CrimeStat: A Spatial statistics program for the analysis of crime incident locations (Vol.II), Ned Levine and Associates, Houston, TX, and the National Institute of Justice, Washington DC.

Liu, L., Eck, J. E. 2008. Artificial Crime Analysis Systems: Using Computer Simulations and Geographic Information Systems, Hershey, IGI Global.

Payne, G. K., 1993. The Provision of basic services in Pakistan, Turkey and Egypt. Urbanization in Developing Countries: Basic Services and Community Participation, ed. Mohanty B., Concept Publishing Company, New Delhi, pp. 17- 
33.

Ratcliffe, J. H. 2004. Strategic Thinking in Criminal Intelligence. Sydney: Federation Press.

Zhang, Y., Hoover, L., Zhao, J., 2016. Geographic Information System Effects on Policing Efficacy: An Evaluation of Empirical in Assessments. International Journal of Applied Geospatial Research (IJAGR), 5(2), pp. 1468-1483.

URL-

1:http://www.tuik.gov.tr/PreHaberBultenleri.do ?id = 10736

URL-2: 'Mavi, B., 2011. Seksen Bir İlin Yaşam Kalitesi Araştırması, CNBC-e Business Dergisi, Eylül 2011, 64- 98.

URL-3: https://www.sahibinden.com/kiralik 